\title{
Potential Health Risk of Endocrine Disruptors in Construction Sector and Plastics Industry: A New Paradigm in Occupational Health
}

\author{
Aleksandra Fucic ${ }^{1}$, Karen S. Galea ${ }^{2}$, Radu Corneliu Duca ${ }^{3}{ }^{(\mathbb{D}}$, Mounia El Yamani ${ }^{4}$, \\ Nadine Frery ${ }^{4}$, Lode Godderis ${ }^{3,5}$ (1) , Thórhallur Ingi Halldorsson ${ }^{6,7}$, Ivo Iavicoli ${ }^{8}$ (D), \\ Sophie Ndaw ${ }^{9}$, Edna Ribeiro ${ }^{10,11,12}$ (D), Susana Viegas ${ }^{10,12}$ (D) and Hanns Moshammer $13, *$ (D) \\ 1 Institute for Medical Research and Occupational Health, 10000 Zagreb, Croatia; afucic@imi.hr \\ 2 Institute of Occupational Medicine (IOM), Centre for Human Exposure Science (CHES), \\ Edinburgh EH14 4AP, UK; karen.galea@iom-world.org \\ 3 Centre for Environment and Health, University of Leuven, 3000 Leuven, Belgium; \\ radu.duca@kuleuven.be (R.C.D.); lode.godderis@kuleuven.be (L.G.) \\ 4 Santé Publique France, French National Public Health Agency, 94415 Saint-Maurice, France; \\ Mounia.ELYAMANI@santepubliquefrance.fr (M.E.Y.); nadine.frery@santepubliquefrance.fr (N.F.) \\ 5 IDEWE, Knowledge, Information and Research Center, 3001 Heverlee, Belgium \\ 6 Unit for Nutrition Research, The National University Hospital of Iceland, 101 Reykjavik, Iceland; tih@hi.is \\ 7 Faculty of Food Science and Nutrition, School of Health Sciences, University of Iceland, \\ 101 Reykjavik, Iceland \\ 8 Department of Public Health, University of Naples Federico II, 80131 Naples, Italy; ivo.iavicoli@unina.it \\ 9 Institut National de Recherche et de Sécurité, Vandoeuvre CEDEX, 54500 Vandœuvre-lès-Nancy, France; \\ sophie.ndaw@inrs.fr \\ 10 H\&TRC - Health \& Technology Research Center, ESTeSL-Escola Superior de Tecnologia da Saúde, \\ Instituto Politécnico de Lisboa, 1990-096 Lisboa, Portugal; edna.ribeiro@estesl.ipl.pt (E.R.); \\ susana.viegas@estesl.ipl.pt (S.V.) \\ 11 Landscape, Environment, Agriculture and Food, Instituto Superior de Agronomia, Universidade de Lisboa, \\ Tapada da Ajuda, 1349-017 Lisboa, Portugal \\ 12 Centro de Investigação e Estudos em Saúde Pública, Escola Nacional de Saúde Pública, Universidade Nova \\ de Lisboa, 1600-560 Lisboa, Portugal \\ 13 Center for Public Health, Medical University of Vienna, 1090 Vienna, Austria \\ * Correspondence: hanns.moshammer@meduniwien.ac.at; Tel.: +43-1-40160-34935
}

Received: 27 April 2018; Accepted: 7 June 2018; Published: 11 June 2018

\begin{abstract}
Endocrine disruptors (EDs) belong to large and diverse groups of agents that may cause multiple biological effects associated with, for example, hormone imbalance and infertility, chronic diseases such as diabetes, genome damage and cancer. The health risks related with the exposure to EDs are typically underestimated, less well characterized, and not regulated to the same extent as, for example, carcinogens. The increased production and utilization of identified or suspected EDs in many different technological processes raises new challenges with respect to occupational exposure settings and associated health risks. Due to the specific profile of health risk, occupational exposure to EDs demands a new paradigm in health risk assessment, redefinition of exposure assessment, new effects biomarkers for occupational health surveillance and definition of limit values. The construction and plastics industries are among the strongest economic sectors, employing millions of workers globally. They also use large quantities of chemicals that are known or suspected EDs. Focusing on these two industries, this short communication discusses: (a) why occupational exposure to EDs needs a more specific approach to occupational health risk assessments, (b) identifies the current knowledge gaps, and (c) identifies and gives a rationale for a future occupational health paradigm, which will include ED biomarkers as a relevant parameter in occupational health risk assessment, surveillance and exposure prevention.
\end{abstract}


Keywords: endocrine disruption; construction sector; plastics industry; fertility; biomarkers

\section{Introduction}

Endocrine disruptors (EDs) belong to a wide range of different substances, which interfere with mammalian hormone biosynthesis, transport, metabolism and receptors, affecting homeostasis, development, and aging, reduce fertility in both sexes and are linked with the etiology of both malignant and non-malignant diseases [1-6]. The biological effects of EDs are complex and do not only depend on dose, but also on the timing of exposure and the sex of the exposed subject [7]. The complex interplay between timing and dose can lead to a broad array of different effects [8]. Effect monitoring therefore requires a battery of specific biomarkers [9]. Moreover, adverse effects linked to ED cannot be forewarned by the classic dose-exposure-response relationship due to their nonlinear dose/effect relationship [10]. Thus, EDs represent a demanding and challenging issue within both the scientific and regulatory context $[9,11]$.

Among the many known effects of EDs, those on male and female reproduction are of especially high concern [5,8]. Knowledge about health risks of EDs and about relevance of exposure reduction is still poor among pregnant women [12]. Similarly, knowledge among workers of both sexes on possible effects of ED on their fertility is certainly not better. While for some effects, late pregnancy might be the most critical time period [13], other effects are of higher concern if exposure occurs in early pregnancy $[14,15]$ or even before the woman is aware of her pregnancy. These early developmental exposures could have long lasting effects in the offspring [16].

Additionally, in construction workers, a significant increase of esophageal, colorectal and gastric cancer was reported [17]. Increased cancer risk (in particular for colorectal, pleural and bladder cancer) was also found in residents living in the vicinity of cement, lime and plaster plants [18]. Testicular cancer was significantly increased in both construction and plastic industry workers [19]. All these cancer types are associated with disturbances of estrogen/testosterone ratio or of their receptors [20-25].

\section{The Need for a New Paradigm in Occupational Health}

In some occupational settings, exposures to EDs are likely to be frequent but also underreported, insufficiently monitored and lacking clear documentation of associations with health effects. Job-Exposure Matrices (JEM) have been developed for that purpose (e.g., [26,27]), but are far from sufficient. To address these deficits, a new paradigm of occupational health assessment, preventive measures and improvements to their regulation is crucial.

European regulations on phthalates, bisphenol and some other EDs have been introduced to reduce health risks of the general population. EU Regulation 2016/2235 added Bisphenol A (BPA) to the REACH Annex XVII Restricted Substances List. This Regulation also restricts the use of some phthalates in polyvinyl chloride (PVC) production and other plasticized materials in all toys and childcare articles, indirectly reducing occupational exposure by the reduced production [28]. Occupational exposure to BPA in inhalable dust is regulated in some countries but not all, although in 2014 the Scientific Committee on Occupational Exposure Limits recommended an 8-h time-weighted average (TWA) of $2 \mathrm{mg} / \mathrm{m}^{3}$ (as inhalable dust) and a biological limit value (BLV) of $7 \mu \mathrm{g} / \mathrm{L}$ (urinary total bisphenol-A) [29].

In this short communication, the construction and plastics industries were selected as examples of two sectors, in which many workers across Europe are exposed to EDs. These include phthalates, bisphenols, aniline, cadmium and chromium [30-38]. 


\section{The Construction and Plastic Industries}

With an annual turnover (total sales) above $€ 1.2$ billion in 2016, the construction sector (including its extended value chain) is the largest single activity and biggest industrial employer (42.9 million direct and indirect jobs; $28.9 \%$ of industrial employment) in Europe (European Construction Industry Federation, Press Release, "Construction industry continues its slow recovery process", 9 June 2017). In 2016, the construction sector amounted to $8.6 \%$ of the EU's total Gross Domestic Product. The European plastic industry turnover was $€ 350$ billion in 2016, with over 1.5 million workers [39]. Global plastics production is projected to reach up to 1.2 billion tons annually by 2050 [40]. In Europe, $20 \%$ of plastics production is used in the construction sector [41] as a response to near zero energy building and zero waste policies in Europe [42-44]. In order to achieve these demands, the construction sector has introduced different classes of plastics, waste and nanomaterials. These new materials retain building structural quality and help seal toxic compounds from waste used as construction material $[45,46]$. However, there is no knowledge of the possible interaction of plastic materials with building materials, which may cause biological effects (synergistic and/or additive effects), and consequently no occupational safety protocols for work with such complex mixtures containing ED.

The increasing need for energy-efficient, sustainable buildings has also resulted in the introduction of new construction and finishing materials made or containing plastic components for water and thermal insulation, flooring, glazing, windows, doors, roofs, paints etc. [47,48]. Plastic monomers and polymers are also used for the production of different concrete types. Additionally, the construction sector produces a huge amount of demolition waste, which may contain heavy metals and other EDs [49]. The EU Construction \& Demolition Waste Management Protocol of 2016 plans special management measures to be implemented for asbestos. However, agents that may have ED properties are not included [50].

\section{Discussion on EDs in Construction and Plastic Industry Technologies}

\subsection{Plastisizers}

There are very few papers on the association of phthalate metabolites levels in plastics industry male workers with the disturbance of estrogen, testosterone levels, sperm motility and testicular cancer [51-53]. An increased risk of infertility in women exposed in the plastic industry has been reported [54]. Occupational studies performed in BPA manufacturers and epoxy resin industries have correlated potential health effects with detected BPA levels in human biological samples. These studies, focused on male vulnerability, report sexual dysfunction, endocrine disruption and epigenetic alterations [55]. Epidemiological evidence has shown significant effects on the offspring of parents exposed to BPA during pregnancy $[56,57]$. Although BPA is partly substituted with bisphenol $\mathrm{F}(\mathrm{BPF})$, it has recently been shown in in vitro and in vivo studies that BPF is more estrogenic than BPA [58-60]. Similarly, bisphenol S and bisphenol B are hormonally active in the same way as BPA or even to a greater extent $[60,61]$. No such studies were evident in the public domain for the construction sector, although exposure to EDs is likely to occur in those employed in finishing and recovery activities, based on emissions data from materials such as vinyl wall and floor coverings [62,63]. Additionally, animal models suggested that pregnancy represents a highly vulnerable period for women with possible risk of diabetes type 2 [64]. Although this warrants further investigations the results might have significant impact on occupational protection of pregnant women.

During the last decade, a new generation of phthalates were introduced that were believed to cause less effects on the human endocrine system. For example, di-isononyl phthalate (DINP) is used as a plasticizer in PVC roof sheets and along with di-isodecyl phthalate (DIDP replacing di-2-ethylhexylphthalate (DEHP)); it is also used in the flooring industry [65]. There is a significant lack of data on endocrine potency of these replacement phthalates. This highlights a need for further investigation especially as in silico results show they interfere with human sex hormone-binding globulin [66] and increase insulin resistance [67]. In 2002, the plasticizer 1,2-cyclohexane dicarboxylic 
acid diisononyl ester (DINCH) was introduced in the European market as a substitute for DEHP. However, animal models recently show that $\mathrm{DINCH}$ is also an ED, which raises the need for further investigation in the human population [68].

\subsection{Heavy Metals and Metalloestrogens}

Heavy metals and metalloestrogens such as cadmium, cobalt, copper, nickel, hexavalent chromium $(\mathrm{Cr}(\mathrm{VI}))$, lead, and mercury are EDs that couple with estrogen receptors and are significantly present both in construction materials and the plastics industry [16,69,70]. Application of fly ash has been reported to significantly increase the risk of exposure to heavy metals in the construction sector [71]. Additionally, despite regulations concerning the application of paint and materials containing heavy metals, they are still in use [72].

New materials to improve the energy efficacy of façades have been introduced, such as cadmium telluride modules [73]. Cadmium carcinogenicity mechanisms include estrogen as one of the signaling pathways [74,75].

Chromium is present in the cement and exposure to cement has been found to be correlated with a higher risk of oligospermia [76] and decreased testosterone levels in exposed men [77]. According to recent data, $\mathrm{Cr}(\mathrm{VI})$ causes sex specific lung cancer risk [78,79]. Paternal occupational exposure to $\mathrm{Cr}(\mathrm{VI})$ is associated with an increased risk of spontaneous abortion in their partners [80]. Although heavy metals in waste used as building materials are sealed, their immobilization is not always equally achieved [81], representing a health risk to workers and future residents. Since Directive 2003/53/EC came into effect [82], all EU Member States have been obliged to reduce the chromate content in cement and cement-containing preparations. Additionally, Regulation No. 1907/2006 (EC, 2006) defines that cement and cement-containing preparations may not be used or placed on the market if they contain, when hydrated, more than $2 \mathrm{ppm}$ of soluble $\mathrm{Cr}(\mathrm{VI})$ of the total dry weight of the cement. The implementation of this Regulation has already showed results in a significant reduction of occupational allergic contact dermatitis in France and the UK [83]. However, in other parts of the World, such as Australia or India, exposure to chromium in cement still remains a problem [84-86].

Lead is a well-known ED $[69,87,88]$ and has been historically used in many different construction materials and paints. As of early 2016, 36\% of countries worldwide have established legally binding limits on lead in paint. Australia, Macedonia, Montenegro, New Zealand, Philippines, Serbia, and Thailand have established a complete ban on lead additives [89]. However, the presence of lead in construction waste can be significant and the risk of exposure is high, especially due to extensive international waste market.

As the only renewable building material, wooden constructions are recommended [90-92]. Despite the fact that long-term wood preservers such as chromated copper arsenate are banned [93], they still represents a problem in the demolition and waste sectors which need detoxification and special workers protection.

\subsection{Other Agents}

Examples of other hazardous substances that are reported to have ED properties are also evident in the published literature. While the following is not a comprehensive list, some examples are provided below.

Current anti-fungal wood preserving technologies including the application of azole compounds have been reported as being aromatase inhibitors and antiandrogens [94] and fetotoxic in animal models [95]. Cypermethrin, a synthetic pyrethroid, used as an insecticide has anti-estrogenic activity [96].

Nonylphenol, used as additive in cement and mortar production, binds to estrogen receptors [97,98].

Aniline is used in shellacs for wood coloring; thus, construction painters and finishing workers are potentially exposed. Aniline is metabolized in paracetamol, which is an antiandrogen substance [36,37], causing hormonal disturbances [99]. 
Nanoparticles, such as titanium dioxide, silicon dioxide and aluminum, which are commonly used as components of construction materials, have also been shown to interact with endocrine system [33].

\section{Conclusions}

The effects of carcinogens are generally well known, and they are regulated more strictly than those for reprotoxic chemicals. Given that xenobiotics may act as EDs at lower doses than they act as carcinogens, pertinent permissible levels to protect worker should be put in place.

Current health surveillance of workers in the construction sector and plastic industry gives very limited insight into the health risks associated with exposure to EDs [100], although the need for the introduction of biomarkers of exposure in health risk assessments has already been recognized [101]. It is considered that the introduction of specific biomarkers of occupational exposure to ED should be included in occupational health surveillance, similar to the collection of anamnestic data on fertility problems, miscarriages and early menopause. Therefore, besides measuring EDs or their metabolites in biological samples, the inclusion of estradiol and testosterone levels which are possible to measure simultaneously with blood screening would already give insight in possible hormonal disturbances without significant increase in biomonitoring costs.

In the plastics industry and construction sector, workers are exposed to complex mixtures of xenobiotics, the effects of which are combined with the lifestyle, diagnostics (radiation) and diet of each person (as is the case for workers in the majority of other industries). Therefore, one of major priorities moving forward is the development of a personal biomonitoring tracking system linked to personal medical records that enables more accurate preventive measures and diagnostics.

In order to achieve this challenging aim, summarized in Figure 1, the authors suggest the following:

(a) Fostering of collaborative studies with a view to collecting and sharing data of biomarkers of occupational exposure to EDs initially in construction sector and plastics industry

(b) Promotion of studies to get further insight in estrogen and testosterone levels and fertility problems on workers occupationally exposed to EDs

(c) Inclusion of sex-specific analyses of occupational health risk

(d) Education of occupational physicians and hygienists, employers and employees and other key stakeholders concerning the EDs co-exposures.

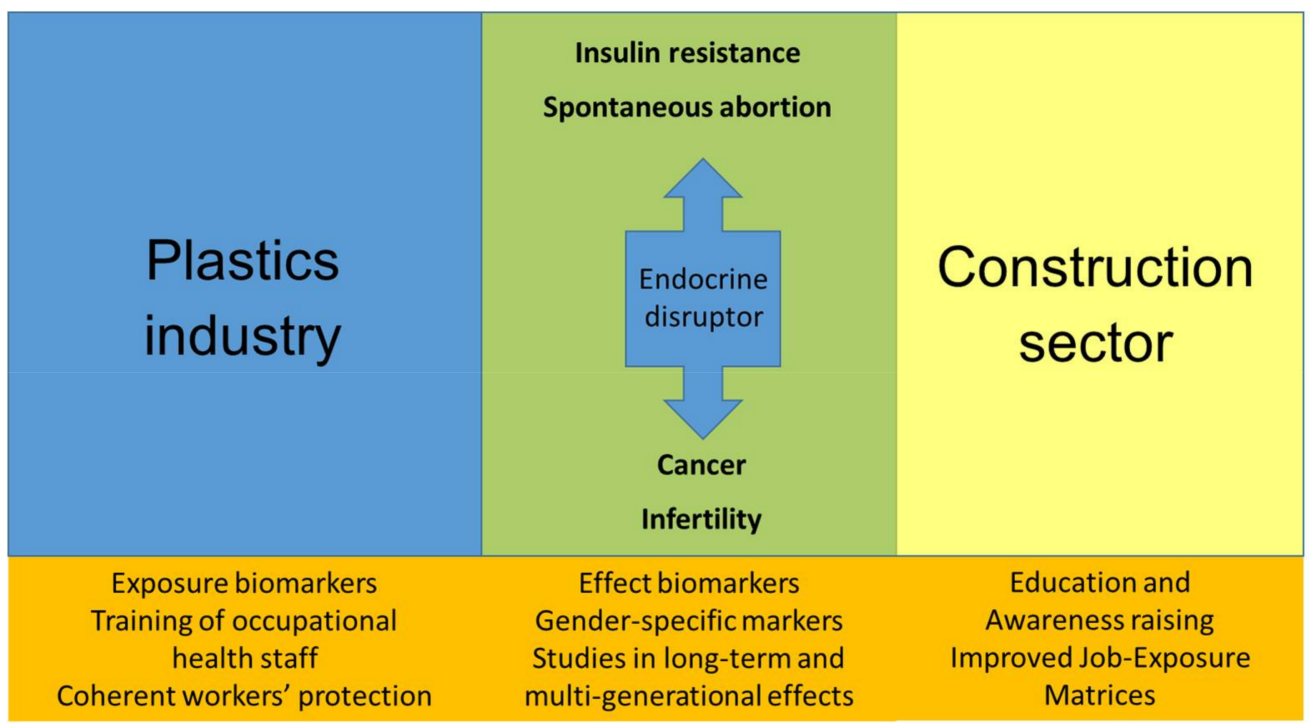

Figure 1. Schematic presentation of the topics and avenues for further research. 
Author Contributions: A.F. and K.S.G. contributed equally in manuscript preparation. Authors listed alphabetically after lead authors. All other authors contributed to the discussion of the topic and provided input to the paper.

Acknowledgments: This short communication was supported through various sources. The Scientific Center of Excellence for Reproductive and Regenerative Medicine and the EU through the European Regional Development Fund No. KK01.1.01.0008, project "Reproduction and Regenerative medicine-Exploring New Platforms and potentials", Medical School University of Zagreb, Zagreb, Croatia, supported the work of A.F. For several co-authors their contributions to the manuscript were unfunded, being covered by their Institutions internal resources.

Conflicts of Interest: The authors declare no conflict of interest.

\section{References}

1. Fucic, A.; Gamulin, M.; Ferencic, Z.; Katic, J.; Krayer von Krauss, M.; Bartonova, A.; Merlo, D.F. Environmental exposure to xenoestrogens and oestrogen related cancers: Reproductive system, breast, lung, kidney, pancreas, and brain. Environ. Health 2012, 11 (Suppl. 1), S8. [CrossRef] [PubMed]

2. Bergman, A.; Heindel, J.J.; Kasten, T.; Kidd, K.A.; Jobling, S.; Neira, M.; Zoeller, R.T.; Becher, G.; Bjerregaard, P.; Bornman, R.; et al. The impact of endocrine disruption: A consensus statement on the state of the science. Environ. Health Perspect. 2013, 121, A104-A106. [CrossRef] [PubMed]

3. Xin, F.; Susiarjo, M.; Bartolomei, M.S. Multigenerational and transgenerational effects of endocrine disrupting chemicals: A role for altered epigenetic regulation? Semin. Cell Dev. Biol. 2015, 43, 66-75. [CrossRef] [PubMed]

4. Kalfa, N.; Paris, F.; Philibert, P.; Orsini, M.; Broussous, S.; Fauconnet-Servant, N.; Audran, F.; Gaspari, L.; Lehors, H.; Haddad, M.; et al. Is hypospadias associated with prenatal exposure to endocrine disruptors? A French collaborative controlled study of a cohort of 300 consecutive children without genetic defect. Eur. Urol. 2015, 68, 1023-1030. [CrossRef] [PubMed]

5. Rattan, S.; Zhou, C.; Chiang, C.; Mahalingam, S.; Brehm, E.; Flaws, J.A. Exposure to endocrine disruptors during adulthood: Consequences for female fertility. J. Endocrinol. 2017, 233, R109-R129. [CrossRef] [PubMed]

6. Solecki, R.; Kortenkamp, A.; Bergman, A.; Chahoud, I.; Degen, G.H.; Dietrich, D.; Greim, H.; Håkansson, H.; Hass, U.; Husoy, T.; et al. Scientific principles for the identification of endocrine-disrupting chemicals: A consensus statement. Arch. Toxicol. 2017, 91, 1001-1006. [CrossRef] [PubMed]

7. McCabe, C.; Anderson, O.S.; Montrose, L.; Neier, K.; Dolinoy, D.C. Sexually Dimorphic Effects of Early-Life Exposures to Endocrine Disruptors: Sex-Specific Epigenetic Reprogramming as a Potential Mechanism. Curr. Environ. Health Rep. 2017, 4, 426-438. [CrossRef] [PubMed]

8. Zoeller, R.T.; Bergman, A.; Becher, G.; Bjerregaard, P.; Bornman, R.; Brandt, I.; Iguchi, T.; Jobling, S.; Kidd, K.A.; Kortenkamp, A.; et al. A path forward in the debate over health impacts of endocrine disrupting chemicals. Environ. Health 2014, 13, 118. [CrossRef] [PubMed]

9. Mihaich, E.M.; Schäfers, C.; Dreier, D.A.; Hecker, M.; Ortego, L.; Kawashima, Y.; Dang, Z.C.; Solomon, K. Challenges in assigning endocrine-specific modes of action: Recommendations for researchers and regulators. Integr. Environ. Assess. Manag. 2017, 13, 280-292. [CrossRef] [PubMed]

10. Vandenberg, L.N.; Colborn, T.; Hayes, T.B.; Heindel, J.J.; Jacobs, D.R.; Lee, D.-H.; Myers, J.P. Hormones and endocrine-disrupting chemicals: Low-dose effects and nonmonotonic dose responses. Endocr. Rev. 2012, 33, 378-455. [CrossRef] [PubMed]

11. Gore, A.C.; Chappell, V.A.; Fenton, S.E.; Flaws, J.A.; Nadal, A.; Prins, G.S.; Toppari, J.; Zoeller, R.T. EDC-2: The Endocrine Society's Second Scientific Statement on Endocrine-Disrupting Chemicals. Endocr. Rev. 2015, 36, E1-E150. [CrossRef] [PubMed]

12. Rouillon, S.; Deshayes-Morgand, C.; Enjalbert, L.; Rabouan, S.; Hardouin, J.-B.; DisProSE, G.; Albouy-Llaty, M. Endocrine Disruptors and Pregnancy: Knowledge, Attitudes and Prevention Behaviors of French Women. Int. J. Environ. Res. Public Health 2017, 14, 1021. [CrossRef] [PubMed]

13. Ohtani, N.; Suda, K.; Tsuji, E.; Tanemura, K.; Yokota, H.; Inoue, H.; Iwano, H. Late pregnancy is vulnerable period for exposure to BPA. J. Vet. Med. Sci. 2018, 80, 536-543. [CrossRef] [PubMed] 
14. Grindler, N.M.; Vanderlinden, L.; Karthikraj, R.; Kannan, K.; Teal, S.; Polotsky, A.J.; Powell, T.L.; Yang, I.V.; Jansson, T. Exposure to Phthalate, an Endocrine Disrupting Chemical, Alters the First Trimester Placental Methylome and Transcriptome in Women. Sci. Rep. 2018, 8, 6086. [CrossRef] [PubMed]

15. Mughal, B.B.; Fini, J.B.; Demeneix, B.A. Thyroid-disrupting chemicals and brain development: An update. Endocr. Connect. 2018, 7, R160-R186. [CrossRef] [PubMed]

16. Philippat, C.; Nakiwala, D.; Calafat, A.M.; Botton, J.; De Agostini, M.; Heude, B.; Slama, R.; EDEN Mother-Child Study Group. Prenatal Exposure to Nonpersistent Endocrine Disruptors and Behavior in Boys at 3 and 5 Years. Environ. Health Perspect. 2017, 125, 097014. [CrossRef] [PubMed]

17. Jansson, C.; Johansson, A.L.; Bergdahl, I.A.; Dickman, P.W.; Plato, N.; Adami, J.; Boffetta, P.; Lagergren, J. Occupational exposures and risk of esophageal and gastric cardia cancers among male Swedish construction workers. Cancer Causes Control. 2005, 16, 755-764. [CrossRef] [PubMed]

18. Garcia-Perez, J.; Lopez-Abente, G.; Castello, A.; Gonzalez-Sanchez, M.; Fernandez-Navarro, P. Cancer mortality in towns in the vicinity of installations for the production of cement, lime, plaster, and magnesium oxide. Chemosphere 2015, 128, 103-110. [CrossRef] [PubMed]

19. Beranger, R.; Le Cornet, C.; Schüz, J.; Fervers, B. Occupational and environmental exposures associated with testicular germ cell tumours: Systematic review of prenatal and life-long exposures. PLoS ONE 2013, 8, e77130. [CrossRef] [PubMed]

20. Nagaraja, V.; Eslick, G.D. Forthcoming prognostic markers for esophageal cancer: A systematic review and meta-analysis. J. Gastrointest. Oncol. 2014, 5, 67-76. [CrossRef] [PubMed]

21. Liang, R.; Lin, Y.; Yuan, C.L.; Liu, Z.H.; Li, Y.Q.; Luo, X.L.; Ye, J.Z.; Ye, H.H. High expression of estrogen-related receptor $\alpha$ is significantly associated with poor prognosis in patients with colorectal cancer. Oncol. Lett. 2018, 15, 5933-5939. [CrossRef] [PubMed]

22. Manente, A.G.; Pinton, G.; Zonca, S.; Tavian, D.; Habib, T.; Jithesh, P.V.; Fennell, D.; Nilsson, S.; Moro, L. KDM6B histone demethylase is an epigenetic regulator of estrogen receptor $\beta$ expression in human pleural mesothelioma. Epigenomics 2016, 8, 1227-1238. [CrossRef] [PubMed]

23. Jukic, Z.; Radulovic, P.; Stojković, R.; Mijic, A.; Grah, J.; Kruslin, B.; Ferencic, Z.; Fucic, A. Gender Difference in Distribution of Estrogen and Androgen Receptors in Intestinal-type Gastric. Cancer Anticancer Res. 2017, 37, 197-202. [CrossRef] [PubMed]

24. Wu, S.; Ye, J.; Wang, Z.; Lin, S.X.; Lu, M.; Liang, Y.; Zhu, X.; Olumi, A.F.; Zhong, W.D.; Wu, C.L. Expression of aromatase in tumor related stroma is associated with human bladder cancer progression. Cancer Biol. Ther. 2018, 19, 175-180. [CrossRef] [PubMed]

25. Lynch, C.; Sakamuru, S.; Huang, R.; Stavreva, D.A.; Varticovski, L.; Hager, G.L.; Judson, R.S.; Houck, K.A.; Kleinstreuer, N.C.; Casey, W.; et al. Identifying environmental chemicals as agonists of the androgen receptor by using a quantitative high-throughput screening platform. Toxicology 2017, 385, 48-58. [CrossRef] [PubMed]

26. Van Tongeren, M.; Nieuwenhuijsen, M.J.; Gardiner, K.; Armstrong, B.; Vrijheid, M.; Dolk, H.; Botting, B. A Job-Exposure Matrix for Potential Endocrine-disrupting Chemicals Developed for a Study into the Association between Maternal Occupational Exposure and Hypospadias. Ann. Occup. Hyg. 2002, 46, 465-477. [PubMed]

27. Brouwers, M.M.; van Tongeren, M.; Hirst, A.A.; Bretveld, R.W.; Roeleveld, N. Occupational exposure to potential endocrine disruptors: Further development of a job exposure matrix. Occup. Environ. Med. 2009, 66, 607-614. [CrossRef] [PubMed]

28. Intertek Group (2015) EU-REACH Amendment-Regulation 2015-326-EU on Polycyclic Aromatic Hydrocarbon and Phthalates. Available online: http:/ / www.intertek.com/consumer/insight-bulletins / reach-amendment-regulation-2015-326-eu/ (accessed on 20 March 2018).

29. SCOEL (2014) Recommendation from the Scientific Committee on Occupational Exposure Limits for Bisphenol-A. SCOEL/SUM/113. European Commission. Available online: Ec.europa.eu/social/BlobServlet? docId=3873\&langId=en (accessed on 20 March 2018).

30. Henson, M.C.; Chedrese, P.J. Endocrine disruption by cadmium, a common environmental toxicant with paradoxical effects on reproduction. Exp. Biol. Med. 2004, 229, 383-392. [CrossRef]

31. Jurasovic, J.; Cvitković, P.; Pizent, A.; Colak, B.; Telisman, S. Semen quality and reproductive endocrine function with regard to blood cadmium in Croatian male subjects. Biometals 2004, 17, 735-743. [CrossRef] [PubMed] 
32. Takiguchi, M.; Yoshihara, S. New aspects of cadmium as endocrine disruptor. Environ. Sci. 2006, 13, $107-116$. [PubMed]

33. Iavicoli, I.; Fontana, L.; Leso, V.; Bergamaschi, A. The effects of nanomaterials as endocrine disruptors. Int. J. Mol. Sci. 2013, 14, 16732-16801. [CrossRef] [PubMed]

34. Byrne, C.; Divekar, S.D.; Storchan, G.B.; Parodi, D.A.; Martin, M.B. Metals and Breast Cancer. J. Mammary Gland Biol. Neoplasia 2013, 18, 63-73. [CrossRef] [PubMed]

35. Rana, S.V. Perspectives in endocrine toxicity of heavy metals-A review. Biol. Trace Elem. Res. 2014, 160, 1-14. [CrossRef] [PubMed]

36. Holm, J.B.; Chalmey, C.; Modick, H.; Jensen, L.S.; Dierkes, G.; Weiss, T.; Jensen, B.A.; Nørregård, M.M.; Borkowski, K.; Styrishave, B.; et al. Aniline is rapidly converted into paracetamol impairing male reproductive development. Toxicol. Sci. 2015, 148, 288-298. [CrossRef] [PubMed]

37. Modick, H.; Weiss, T.; Dierkes, G.; Koslitz, S.; Käfferlein, H.U.; Brüning, T.; Koch, H.M. Human metabolism and excretion kinetics of aniline after a single oral dose. Arch. Toxicol. 2016, 90, 1325-1333. [CrossRef] [PubMed]

38. Banu, S.K.; Stanley, J.A.; Sivakumar, K.K.; Arosh, J.A.; Burghardt, R.C. Resveratrol protects the ovary against chromium-toxicity by enhancing endogenous antioxidant enzymes and inhibiting metabolic clearance of estradiol. Toxicol. Appl. Pharmacol. 2016, 303, 65-78. [CrossRef] [PubMed]

39. Plastics Europe (2017) Plastics-The Facts 2017. Available online: https://www.plasticseurope.org/ application/files/5715/1717/4180/Plastics_the_facts_2017_FINAL_for_website_one_page.pdf (accessed on 20 March 2018).

40. Sartorius, I.; Joachim Wuttke, J. Sustainable Management and Recovery Potential of Plastic Waste from the Commercial and Private Household Sectors. Available online: https:/ /www.wastematters.eu/uploads / media/SMM_Presentation_Ingo_Sartorius_Plastics.pdf (accessed on 27 April 2018).

41. Plastics in Building and Construction. Available online: https:/ /www.plasticseurope.org/en/about-plastics / building-construction (accessed on 9 June 2018).

42. COM/2014/0398. Communication from the Commission to the European Parliament, the Council, the European Economic and Social Committee and the Committee of the Regions: Towards a Circular Economy: A Zero Waste Programme for Europe. Available online: https:/ / eur-lex.europa.eu/resource.html?uri=cellar: 50edd1fd-01ec-11e4-831f-01aa75ed71a1.0001.01/DOC_1\&format=PDF (accessed on 27 April 2018).

43. EU Directive on the Energy Performance of Buildings Directive 2010/31/EU. Available online: http: / / eurlex.europa.eu/LexUriServ/LexUriServ.do?uri=OJ:L:2010:153:0013:0035:EN:PDF (accessed on 27 April 2018).

44. Directive 2009/28/EC Of the European Parliament and of the Council of 23 April 2009 on the Promotion of the Use of Energy from Renewable Sources and Amending and Subsequently Repealing Directives 2001/77/EC and 2003/30/EC. Available online: https: / / eur-lex.europa.eu/legal-content/EN/TXT/PDF/?uri=CELEX: 32009L0028\&from $=$ EN (accessed on 27 April 2018).

45. Fucic, A. The main health hazards from building materials. In Toxicity of Building Materials; Pacheco-Torgal, F., Jalali, S., Fucic, A., Eds.; Woodhead: Cambridge, UK, 2012; pp. 1-22.

46. Isnin, Z.; Ahmad, S.; Yahya, Z. Challenges of the Unknown Building Material Substances for Greener Adaptation Projects. Procedia Soc. Behav. Sci. 2012, 68, 53-62. [CrossRef]

47. Liew, K.M.; Sojobi, A.O.; Zhang, L.W. Green concrete: Prospects and challenges. Constr. Build. Mater. 2017, 156, 1063-1095. [CrossRef]

48. Rudel, R.A.; Perovich, L.J. Endocrine disrupting chemicals in indoor and outdoor air. Atmos. Environ. 2009, 43, 170-181. [CrossRef] [PubMed]

49. Chakrawarthi, V.; Darmar, B.; Elangovan, A. Copper slag concrete admixed with polypropylene fibres. Gradevinar 2016, 68, 95-178. [CrossRef]

50. European Commission. EU Construction and Demolition Waste Protocol. Available online: https:/ / ec.europa. eu/growth/content/eu-construction-and-demolition-waste-protocol-0_en (accessed on 27 April 2018).

51. Fong, J.P.; Lee, F.J.; Lu, I.S.; Uang, S.N.; Lee, C.C. Relationship between urinary concentrations of di(2-ethylhexyl) phthalate (DEHP) metabolites and reproductive hormones in polyvinyl chloride production workers. Occup. Environ. Med. 2015, 72, 346-353. [CrossRef] [PubMed]

52. Huang, L.P.; Lee, C.C.; Hsu, P.C.; Shih, T.S. The association between semen quality in workers and the concentration of di(2-ethylhexyl) phthalate in polyvinyl chloride pellet plant air. Fertil. Steril. 2011, 96, 90-94. [CrossRef] [PubMed] 
53. Ohlson, C.G.; Hardell, L. Testicular cancer and occupational exposures with a focus on xenoestrogens in polyvinyl chloride plastics. Chemosphere 2000, 40, 1277-1282. [CrossRef]

54. Hougaard, K.S.; Hannerz, H.; Feveile, H.; Bonde, J.P. Increased incidence of infertility treatment among women working in the plastics industry. Reprod. Toxicol. 2009, 27, 186-189. [CrossRef] [PubMed]

55. Ribeiro, E.; Ladeira, C.; Viegas, S. EDCs mixtures: A stealthy hazard for human health? Toxics 2017, 5, 5. [CrossRef] [PubMed]

56. Miao, M.; Yuan, W.; Zhu, G.; He, X.; Li, D.K. In utero exposure to bisphenol-A and its effect on birth weight of offspring. Reprod. Toxicol. 2011, 32, 64-68. [CrossRef] [PubMed]

57. Ribeiro, E.; Ladeira, C.; Viegas, S. Occupational exposure to Bisphenol A (BPA): A reality that still needs to be unveiled. Toxics 2017, 5, 22. [CrossRef] [PubMed]

58. Rochester, J.R.; Bolden, A.L. Bisphenol S and F: A systematic review and comparison of the hormonal activity of Bisphenol A substitutes. Environ. Health Perspect. 2015, 123, 643-650. [CrossRef] [PubMed]

59. Mesnage, R.; Phedonos, A.; Arno, M.; Balu, S.; Corton, J.C.; Antoniou, M.N. Editor's Highlight: Transcriptome profiling reveals Bisphenol A alternatives activate estrogen receptor alpha in human breast cancer cells. Toxicol. Sci. 2017, 158, 431-443. [CrossRef] [PubMed]

60. Zhang, Z.B.; Hu, Y.; Guo, J.; Yu, T.; Sun, Y.L.; Xiao, X.; Desheng, D.; Nakanishi, T.; Hiromori, Y.; Li, J.; et al. Fluorene-9-bisphenol is anti-oestrogenic and may cause adverse pregnancy outcomes in mice. Nat. Comm. 2017, 8, 14585. [CrossRef] [PubMed]

61. Cao, L.Y.; Ren, X.M.; Li, C.H.; Zhang, J.; Qin, W.P.; Yang, Y.; Wan, B.H.; Bisphenol, A.F.; Bisphenol, B. Exert Higher Estrogenic Effects than Bisphenol A via G Protein-Coupled. Estrogen Receptor Pathway. Environ. Sci. Technol. 2017, 51, 11423-11430. [CrossRef] [PubMed]

62. Yu, C.; Crump, D. A review of the emission of VOCs from polymeric materials used in buildings. Build. Environ. 1998, 33, 357-374. [CrossRef]

63. Xu, Y.; Hubal, E.A.; Clausen, P.A.; Little, J.C. Predicting residential exposure to phthalate plasticizer emitted from vinyl flooring: A mechanistic analysis. Environ. Sci. Technol. 2009, 43, 2374-2380. [CrossRef] [PubMed]

64. Blesson, C.S.; Yallampalli, C. Pregnancy is a New Window of Susceptibility for Bisphenol A Exposure. Endocrinology 2015, 156, 1611-1612. [CrossRef] [PubMed]

65. KEMI (Swedish Chemicals Agency). Phthalates Which Are Toxic for Reproduction and EndocrineDisrupting - Proposals for a Phase-Out in Sweden Report from a Government Assignment; Report 4/15; Swedish Chemical Agency: Sundbyberg, Sweden, 2015; ISSN 0284-1185. Available online: https:/ / www.kemi.se/ global/rapporter / 2015/report-4-15-phatalates.pdf (accessed on 20 March 2018).

66. Sheikh, I.A.; Yasir, M.; Abu-Elmagd, M.; Dar, T.A.; Abuzenadah, A.M.; Damanhouri, G.A.; Al-Qahtani, M.; Beg, M.A. Human sex hormone-binding globulin as a potential target of alternate plasticizers: An in silico study. BMC Struct. Biol. 2016, 16 (Suppl. 1), 15. [CrossRef] [PubMed]

67. Attina, T.M.; Trasande, L. Association of Exposure to Di-2-Ethylhexylphthalate Replacements with increased insulin resistance in adolescents from NHANES 2009-2012. J. Clin. Endocrinol. Metab. 2015, 100, 2640-2650. [CrossRef] [PubMed]

68. Campioli, E.; Sunghoon, L.; Lau, M.; Marques, L.; Papadopoulos, V. Effect of prenatal DINCH plasticizer exposure on rat offspring testicular function and metabolism. Sci. Rep. 2017, 7, 11072. [CrossRef] [PubMed]

69. Martin, M.B.; Reiter, R.; Pham, T.; Avellanet, Y.R.; Camara, J.; Lahm, M.; Pentecost, E.; Pratap, K.; Gilmore, B.A.; Divekar, S.; et al. Estrogen-like activity of metals in MCF-7 breast cancer cells. Endocrinol. 2003, 144, 2425-2436. [CrossRef] [PubMed]

70. Iavicoli, I.; Fontana, L.; Bergamaschi, A. The effects of metals as endocrine disruptors. J. Toxicol. Environ. Health B Crit. Rev. 2009, 12, 206-223. [CrossRef] [PubMed]

71. Lederer, J.; Trinkel, V.; Fellner, J. Wide-scale utilization of MSWI fly ashes in cement production and its impact on average heavy metal contents in cements: The case of Austria. Waste Manag. 2017, 60, 247-258. [CrossRef] [PubMed]

72. Turner, A.; Kearl, E.R.; Solman, K.R. Lead and other toxic metals in playground paints from South West England. Sci. Total Environ. 2016, 544, 460-466. [CrossRef] [PubMed]

73. Sorgato, M.J.; Schneider, K.; Rüther, R. Technical and economic evaluation of thin-film CdTe buildingintegrated photovoltaics (BIPV) replacing façade and rooftop materials in office buildings in a warm and sunny climate. Renew. Energy 2018, 118, 84-98. [CrossRef] 
74. Stoica, A.; Katzenellenbogen, B.S.; Martin, M.B. Activation of estrogen receptor-alpha by the heavy metal cadmium. Mol. Endocrinol. 2000, 14, 545-553. [CrossRef] [PubMed]

75. Chen, P.; Duan, X.; Li, M.; Huang, C.; Li, J.; Chu, R.; Ying, H.; Song, H.; Jia, X.; Ba, Q.; et al. Systematic network assessment of the carcinogenic activities of cadmium. Toxicol. Appl. Pharmacol. 2016, 310, 150-158. [CrossRef] [PubMed]

76. Daoud, S.; Sellami, A.; Bouassida, M.; Kebaili, S.; Ammar Keskes, L.; Rebai, T.; Chakroun Feki, N. Routine assessment of occupational exposure and its relation to semen quality in infertile men: A cross-sectional study. Turk. J. Med. Sci. 2017, 47, 902-907. [CrossRef] [PubMed]

77. Rotter, I.; Kosik-Bogacka, D.I.; Dołegowska, B.; Safranow, K.; Kuczynska, M.; Laszczynska, M. Analysis of the relationship between the sblood concentration of several metals, macro- and micronutrients and endocrine disorders associated with male aging. Environ. Geochem. Health 2016, 38, 749-761. [CrossRef] [PubMed]

78. Behrens, T.; Pesch, B.; Vermeulen, R.; Olsson, A.; Schüz, J.; Portengen, L.; Kendzia, B.; Kromhout, H.; Straif, K.; Brüning, T.; et al. Exposure to hexavalent chromium and nickel and lung cancer risk: A pooled analysis of case-control studies from Europe and Canada. Occup. Environ. Med. 2017, 74 (Suppl. 1), A152.

79. Khadem, M.; Golbabaei, F.; Rahmani, A. Occupational exposure assessment of Chromium (VI): A review of environmental and biological monitoring. Int. J. Occup. Hygene 2017, 9, 118-131.

80. Hjollund, N.H.; Bonde, J.P.; Jensen, T.K.; Henriksen, T.B.; Andersson, A.M.; Kolstad, H.A.; Ernst, E.; Giwercman, A.; Skakkebaek, N.E.; Olsen, J. Male-mediated spontaneous abortion among spouses of stainless steel welders. Scand. J. Work Environ. Health 2000, 26, 187-192. [CrossRef] [PubMed]

81. Giergiczny, Z.; Krol, A. Immobilization of heavy metals ( $\mathrm{Pb}, \mathrm{Cu}, \mathrm{Cr}, \mathrm{Zn}, \mathrm{Cd}, \mathrm{Mn})$ in the mineral additions containing concrete composites. J. Hazard Mater. 2008, 160, 247-255. [CrossRef] [PubMed]

82. Official Journal of the European Union. DIRECTIVE 2003/53/EC OF THE EUROPEAN PARLIAMENT AND OF THE COUNCIL of 18 June 2003 Amending for the 26th Time Council Directive 76/769/EEC Relating to Restrictions on the Marketing and Use of Certain Dangerous Substances and Preparations (Nonylphenol, Nonylphenol Ethoxylate and Cement). 2003. Available online: http://eur-lex.europa.eu/LexUriServ/ LexUriServ.do?uri=OJ:L:2003:178:0024:0027:en:PDF (accessed on 21 March 2018).

83. Bensefa-Colas, L.; Stocks, S.J.; McNamee, R.; Faye, S.; Pontin, F.; Agius, R.M.; Lasfargues, G.; RNV3P members; Telle-Lamberton, M.; Momas, I. Effectiveness of the European chromium(VI) directive for cement implementation on occupational allergic contact dermatitis occurrence: Assessment in France and the U.K. Br. J. Dermatol. 2017, 177, 873-876. [CrossRef] [PubMed]

84. Hwang, S.H.; Park, J.B.; Lee, K.J. Exposure assessment of particulate matter and blood chromium levels in people living near a cement plant. Environ. Geochem. Health 2017. [CrossRef] [PubMed]

85. Wong, C.C.; Gamboni, S.E.; Palmer, A.M.; Nixon, R.L. Occupational allergic contact dermatitis to chromium from cement: Estimating the size of the problem in Australia. Australas J. Dermatol. 2015, 56, 290-293. [CrossRef] [PubMed]

86. Sharma, R.; Sharma, D.; Katyal, N.K. Study of total chromium and water soluble chromium in Indian cement samples. IJOART 2014, 2, 1-5. [CrossRef]

87. Rzymski, P.; Tomczyk, K.; Rzymski, P.; Poniedziałek, B.; Opala, T.; Wilczak, M. Impact of heavy metals on the female reproductive system. Ann. Agric. Environ. Med. 2015, 22, 259-264. [CrossRef] [PubMed]

88. Kasten-Jolly, J.; Lawrence, D.A. Sex-specific effects of developmental lead exposure on the immune-neuroendocrine network. Toxicol. Appl. Pharmacol. 2017, 334, 142-157. [CrossRef] [PubMed]

89. UNEP. Global Report on the Status of Legal Limits on Lead in Paint. United Nations Environmental Program, 2016. Available online: https://wedocs.unep.org/bitstream/handle/20.500.11822/11348/Limits-LeadPaint-2016\%20Report-Final.pdf?sequence=1\&isAllowed=y (accessed on 21 March 2018).

90. Petersen, A.K.; Solberg, B. Environmental and economic impacts of substitution between wood products and alternative materials: A review of micro-level analyses from Norway and Sweden. For. Policy Econ. 2005, 7, 249-259. [CrossRef]

91. Ritter, M.A.; Skog, K.; Bergman, R. Science Supporting the Economic and Environmental Benefits of Using Wood and Wood Products in Green Building Construction; General Technic Report FPL-GTR-206; U.S. Department of Agriculture, Forest Service, Forest Products Laboratory: Madison, WI, USA, 2011.

92. Herczeg, M.; McKinnon, D.; Milios, L.; Bakas, I.; Klaassens, E.; Svatikova, K.; Widerberg, O. Resource Efficiency in the Building Sector; Final Report; Prepared for European Commission by ECORYS and Copenhagen Resource Institute: Rotterdam, The Netherlands, 2014. 
93. Commission Directive 2003/2/EC. Relating to Restrictions on the Marketing and Use of Arsenic (Tenth Adaptation to Technical Progress to Council Directive 76/769/EEC. Available online: https:/ /www.tid.gov. hk/english/aboutus/tradecircular/cic/eu/2003/files/ci552003a.pdf (accessed on 8 June 2018).

94. Kjærstad, M.B.; Taxvig, C.; Nellemann, C.; Vinggaard, A.M.; Andersen, H.R. Endocrine disrupting effects in vitro of conazole antifungals used as pesticides and pharmaceuticals. Reprod. Toxicol. 2010, 30, 573-582. [CrossRef] [PubMed]

95. Taxvig, C.; Vinggaard, A.M.; Hass, U.; Axelstad, M.; Metzdorff, S.; Nellemann, C. Endocrine-disrupting properties in vivo of widely used azole fungicides. Int. J. Androl. 2008, 31, 170-177. [CrossRef] [PubMed]

96. Kojima, M.; Fukunaga, K.; Sasaki, M.; Nakamura, M.; Tsuji, M.; Nishiyama, T. Evaluation of estrogenic activities of pesticides using an in vitro reporter gene assay. Int. J. Environ. Health Res. 2005, 15, 271-280. [CrossRef] [PubMed]

97. Blume, B.; Kietzmann, M.; Kranke, P.; Moder, M.; Schrader, S.; Wahren, M. Deuterium labelled nonylphenols in an in-vitro model of percutaneous absorption of environmental xenoestrogens. Isot. Environ. Health Stud. 2000, 36, 3-9. [CrossRef] [PubMed]

98. Noorimotlagh, Z.; Haghighi, N.J.; Ahmadimoghadam, M.; Rahim, F. An updated systematic review on the possible effect of nonylphenol on male fertility. Environ. Sci. Pollut. Res. Int. 2017, 24, 3298-3314. [CrossRef] [PubMed]

99. Hay-Schmidt, A.; Finkielman, O.T.E.; Jensen, B.A.H.; Høgsbro, C.F.; Bak Holm, J.; Johansen, K.H.; Jensen, T.K.; Andrade, A.M.; Swan, S.H.; Bornehag, C.G.; et al. Prenatal exposure to paracetamol/acetaminophen and precursor aniline impairs masculinisation of male brain and behaviour. Reproduction 2017, 154, 145-152. [CrossRef] [PubMed]

100. Caporossi, L.; Papaleo, B. Bisphenol A and Metabolic Diseases: Challenges for Occupational Medicine. Int. J. Environ. Res. Public Health 2017, 14, 959. [CrossRef] [PubMed]

101. Takeuchi, A.; Ogawa, Y.; Endo, Y.; Kawai, T.; Namera, A.; Yamamuro, K.; Sumino, K.; Endo, G. Evaluation of urinary cyclohexanediols and cyclohexanol as biomarkers of occupational exposure to cyclohexane. J. Occup. Health 2015, 57, 365-370. [CrossRef] [PubMed]

(C) 2018 by the authors. Licensee MDPI, Basel, Switzerland. This article is an open access article distributed under the terms and conditions of the Creative Commons Attribution (CC BY) license (http://creativecommons.org/licenses/by/4.0/). 